\title{
NEW DATA ON DISTRIBUTION AND TAXONOMY OF SOME SPECIES IN LOPHOZIACEAE (HEPATICAE)
}

\author{
НОВЫЕ СВЕДЕНИЯ О РАСПРОСТРАНЕНИИ И ТАКСОНОМИИ \\ НЕКОТОРЫХ ВИДОВ СЕМЕЙСТВА LOPНOZIAСЕАЕ (HЕРАТІСАЕ)
}

\author{
VADIM A. BAKALIN ${ }^{1}$ \\ ВАДИМ АНДРЕЕВИЧ БАКАЛИН ${ }^{1}$
}

Abstract

Lophozia ventricosa var. longiflora (Nees) Macoun is recorded for South Shetland Islands; this is the second report of the taxon for the Southern Hemisphere. Isopaches bicrenatus (Hoffm.) H.Buch is reported for the first time from Central America, in Dominican Republic. A new combination Isopaches pumicicola (Berggr.) Bakalin comb. nov. is proposed. Tritomaria mexicana Bakalin sp. nov. is described as new to science. The diagnostic characters of the new species include 2-lobed leaves with equal to slightly subequal lobes and 1-celled angular gemmae, the combination unknown in any other member of the genus.

Резюме

Lophozia ventricosa var. longiflora (Nees) Macoun приводится для Южных Шетландских островов, эта вторая находка вида в Южном полушарии. Isopaches bicrenatus (Hoffm.) H. Buch впервые приводится для Центральной Америки (Доминиканская Республика). Предложена новая комбинация Isopaches pumicicola (Berggr.) Bakalin comb. nov. Tritomaria mexicana Bakalin sp. nov. описана как новый для науки вид. Таксономически важными характеристиками нового вида являются двулопастные листья с симметричными до слегка несимметричных лопастями и 1-клеточные выводковые почки. Такое сочетание не известно у других представителей рода.

In the course of preparation of the treatment of Lophozia and allied genera for the Flora of North America I have also studied collection of Lophoziaceae from some other areas. Interesting findings and one new species are discussed in the present paper.

\section{Lophozia ventricosa var. longiflora (Nees) Macoun \\ I have reported (Bakalin, 2005) that Lophozia ventricosa sometimes occurs in the Subantarctic Region. A new locality of this species from South Shetland Islands is an addition to the previously known place of $L$. ventricosa var. longiflora (Nees) Macoun in South Georgia. This collection has been previously issued in 'Bryophyta Antarctica Exs-}

iccatae', N. 124 as Lophozia excisa (Dicks.) Dumort. Plants in the specimen bear obviously whitish to greenish gemmae, and are in other features indistinguishable from the typical Lophozia ventricosa var. longiflora.

Specimen examined: Antarctic South Shetland Islands. King Georg Island: Maxwell Bay, Ardley Island near Fildes Peninsula. $62^{\circ} 13^{\prime} \mathrm{S}-58^{\circ} 56^{\prime} \mathrm{W}, 15 \mathrm{~m}$ alt. In turfs of Polytrichum strictum on the surface of deep peat bank on gently sloping ground. Coll. R Ochyra 2.III.1980 (F-1061992).

Bednarek-Ochyra et al. (2000) recorded $L$. cf. groenlandica (Nees) Macoun for Antarctic. They indicate for the latter lax, polymorphous and sometimes trilobed leaves with deep sinus, to $1 / 2$ of leaf length. These characters indicate that this tax-

1 - Institute of Biology and Soil Science, 100 let Vladivostoku Street, 159, Vladivostok, 690022, Russia-v_bak@list.ru 
on is rather $L$. ventricosa var. ventricosa, not $L$. groenlandica. Distinction between these two polymorphous taxa is discussed by Bakalin (2005).

2. Isopaches bicrenatus (Schmid. ex Hoffm.) H. Buch

There are four species of Isopaches worldwide. One of them: Isopaches pumicicola (Berggr.) Bakalin comb. nov. (Basionym: Lophozia pumicicola Berggr. 1898. New Zealand Hepaticae, 21) is distributed in New Zealand, the other three are confined mainly to the Northern Hemisphere, although Isopaches decolorans penetrates deeply into the Paleotropics (Gradstein \& Vana, 1987), reaching equatorial Africa and I. bicrenatus has disjunctive localities in New Zealand and Brazil (Engel \& Glenny, 2008; Gradstein \& Pinheiro da Costa, 2003).

The specimen of the latter species was revealed also in Central America: Dominican Republic. Provincia La Vega: vicinity of pyramids, $13.8 \mathrm{~km}$ $\mathrm{S}$ of Valle Nuevo, $44 \mathrm{~km} \mathrm{~S}$ of Constanza. ca. $18^{\circ} \mathrm{N}$ $70^{\circ} \mathrm{W}, 2250 \mathrm{~m}$.s.1. Humid steep ravine and adjacent fields. Coll. W.R. Buck 30 April 1982, field number 8070 (NY-00670928).

Plants in the sample bear perianths, antheridia and gemmae. The inflorescence is mostly paroicous, but also heteroicous, with some antheridial innovations. The latter condition is unusual in this species, and was described by Schuster (1995) based on North American material. The perianth mouth is crenulate (not spinose-ciliate as in I. bicraenatus), and both female and male bracts have entire margins. Plants bear copious rusty-red gemmae and have a strong cedar oil fragrance; these are quite characteristic of this species. The purplish color of shoots is, however, unusual for this species.

3. A new species of Tritomaria from southern Mexico.

The genus Tritomaria s. str. includes six species distributed mainly in cold regions of the Northern Hemisphere, although two species, T. exsectiformis and $T$. exsecta reach the zone of broad-leaved deciduous forest to the south. One species, T. camerunensis S.W. Arnell, was described from Cameroon Mountains in equatorial Africa and is known only from that area. In the course of my recent studies of Lophozia genus at the Missouri Botanical Garden, I found a new species of Tritomaria from the southern part of Mexico.
Tritomaria mexicana Bakalin sp. nov.

Plantae dioicae, ascendentes, vivide virides vel brunneolae vel flavo-virescentes. Caules in sectione transversali strato microcelluloso usque ad 1/4 portionem altitudinis caulis. Folia subtransverse inserta, lobis aequalibus vel subaequalibus, cuticula distincte striolato-verrucosa, parietibus tenuibus, trigonis concavis. Gemmae rubrae, rubiginosae vel purpureo-nigricantes, unicellulares, in angulis valde protrudentes. Perianthium ad orem abrupte contractum, ca. (1.7) 2.0-22.5 $\times 0.6-0.7 \mathrm{~mm}$, ore ciliato, ciliis per longitudinem 4(-5) cellularum longis, plerumque unistratosum.

Holotypus: Mexico. Michoacan: San Juan Nuevo, Patzingo $\left(19^{\circ} 28^{\prime} \mathrm{N}, 102^{\circ} 11^{\prime} \mathrm{W}\right), 2400 \mathrm{~m}$ alt. On tree base in rather open montane Pine-Oak forest. leg. M. Burghardt 06 Oct. 2004 № 4512. (MO-5366378, isotypus in VLA).

Plants $5-10(-13) \times 1.6-2.0 \mathrm{~mm}$, ascending, bright green to brownish or yellowish green. Stems to $135-150 \mu \mathrm{m}$ in height and ca. $170-190 \mu \mathrm{m}$ in width, sparsely branching, transverse section with microcellous layer up to $1 / 4$ of stem height, cell walls thickened along margin, ventral surface redbrown; rhizoids common, originating from dorsal side of stem at right angles, ca. $3 \mathrm{~mm}$ length. Leaves subtransversely inserted, spreading to erect-spreading, somewhat sulcate, distant, with apices deflected from the apex, oval to ovate, $0.6-0.8 \times 0.53$ $0.65 \mathrm{~mm}$, lobes equal to subequal, divided by a Ushaped sinus descending to $1 / 4-1 / 3$ of leaf length, lobes with acute to obtuse apices, top of stem bearing clusters of gemmae; cells of midleaf nearly subquadrate to rectangular, (12-)14-22(-25) x (12)14-22(-25) $\mu \mathrm{m}$, in leaf base to $25-30 \mu \mathrm{m}$ in length; cuticle distinctly striolate verrucose, walls thin, trigones concave; oil-bodies spherical to shortly ellipsoidal, 3-3.5 x 3.5-6 $\mu \mathrm{m}$, faintly papillose, 4-8 per cell; underleaves absent. Specialized asexual reproduction by gemmae at apex of shoots, red, rustyred to blackish purple, commonly pentagonal to polygonal in shape, 18-23 x 20-26 $\mu \mathrm{m}, 1$-celled, with strongly protruding angles. Sexual condition dioicous. Androecia unknown. Gynoecia terminal, commonly with one or two ventral innovations, female bracts in 1 pair, obovate, entire, ca. $1.11-1.15$ $\mathrm{x} 0.8-1.0 \mathrm{~mm}$, divided to $1 / 4$ of their length into 2 acute lobes with entire margins by a gibbous sinus, 
Table 1. A comparison of Tritomaria mexicana with related species (* - based on Arnell, 1958).

\begin{tabular}{|c|c|c|c|}
\hline Feature & T. mexicana & T. exsectiformis & T. camerunensis* \\
\hline Width of shoots, mm & $1.6-2.0$ & $1.6-2.0$ & ca. $0.8-1.2$ \\
\hline Width of stem, $\mu \mathrm{m}$ & $170-190$ & $240-275$ & $180-240$ \\
\hline Size of leaves, mm & $0.6-0.8 \times 0.53-0.65$ & $0.8-0.9 \times 0.75-0.9$ & ca. $0.6 \times 0.5$ \\
\hline Number of lobes & 2 & $(2-) 3$ & $2-3$ \\
\hline Lobes & equal to subequal & $\begin{array}{l}\text { unequally } 3 \text {-lobed or more rarely } \\
\text { strongly asymmetrically 2-lobed }\end{array}$ & $\begin{array}{l}\text { unequal to } \\
\text { strongly unequal }\end{array}$ \\
\hline Shape of sinus & U-shaped & angular to U-shaped & gibbous \\
\hline Midleaf cell length, $\mu \mathrm{m}$ & $(12-) 14-22(-25)$ & $20-36(-40)$ & ca. 30 \\
\hline Midleaf cell width, $\mu \mathrm{m}$ & $(12-) 14-20(-25)$ & $17-22$ & ca. 20 \\
\hline Midleaf cell walls & thin & thin & thick \\
\hline Trigones & small, concave & bulging & distinct, convex \\
\hline Oil-bodies n per cells & $4-8$ per cell & $(6-9-) 12-15$ per cell & no data \\
\hline Oil-bodies shape & $\begin{array}{l}\text { spherical to shortly ellipsoidal, } \\
\text { faintly papillose }\end{array}$ & $\begin{array}{l}\text { spherical to ovoid } \\
\text { faintly papillose }\end{array}$ & $\begin{array}{l}\text { no data } \\
\text { no data }\end{array}$ \\
\hline Oil-bodies size, $\mu \mathrm{m}$ & $3-3.5 \times 3.5-6$ & $3.0-4.5 \times 4.0-5.5$ & no data \\
\hline Gemmae & 1-celled, angular & 2-celled, angular & $\begin{array}{l}\text { 1-celled rounded } \\
\text { to } 2 \text {-celled angular }\end{array}$ \\
\hline Gemmae, size, $\mu \mathrm{m}$ & $18-23 \times 20-26$ & $13-20 \times 16-26$ & $14 \times 14-22$ \\
\hline Bracts & $\begin{array}{l}\text { divided into } 2 \text { acute subequal } \\
\text { lobes with entire margin } \\
\text { by gibbous sinus }\end{array}$ & $\begin{array}{l}\text { divided into (2-)2-5 strongly } \\
\text { unequal lobes with entire margin } \\
\text { and angular to U-shaped sinus }\end{array}$ & no data \\
\hline Perianth exertion & exerted to $5 / 6$ of its length, & exerted to $3 / 4$ of its length, & no data \\
\hline Perianth shape & abruptly constricted to mouth & contracted to mouth & \\
\hline Perianth size & $(1.7-) 2.0-2.5 \times 0.6-0.7 \mathrm{~mm}$ & ca. $2.0 \times 1.0 \mathrm{~mm}$ & \\
\hline
\end{tabular}

not connate, bracteole absent. Perianth exerted to 5/ 6 of its length, cylindrical-subclavate, tightened to mouth, ca. (1.7-)2.0-2.5 x 0.6-0.7 mm, mouth ciliate with cilia to $4(-5)$ cells long, generally 1 -stratose. Sporophyte unknown.

The species is most closely related to $T$. camerunensis and T. exsectiformis. The distinctions between three taxa given in Table 1.

The diagnostic characters of the new species include 2-lobed leaves with equal to slightly subequal lobes, and 1-celled angular gemmae, a combination not known in other members of the genus. Arnell (1958) indicates for T. camerunensis 1-2-celled gemmae, but described 1-celled ones only as oval. I presume these 1-celled gemmae in $T$. camerunensis may be only immature, become angular and 2-celled at maturity. The same phenomenon occurs frequently in other Lophozia species.
Currently the species is known only from the type and data on its ecology are incomplete.

The specimen was identified previously as $\mathrm{Lo}$ phozia cf. longidens by J. Vana. Actually confusion of the species with Lophozia is hardly possible, due to presence of certain unique features inherent Tritomaria: strongly and thoroughly papillose leaf cuticle, abruptly contracted perianth mouth, and the absence of bracteole.

\section{ACKNOWLEDGEMENTS}

I am deeply obliged to Dr. R. Zander for constant attention and help in this account, as well as support of the Flora of North America Association for my work at the Missouri Botanical Garden, and to Dr. P. Eckel for preparation of Latin translation. I am very grateful to Dr. B. Allen for the duplicate of isotype of Tritomaria mexicana granted to VLA. This work was partially supported by RFBR, 06-05-64137. 

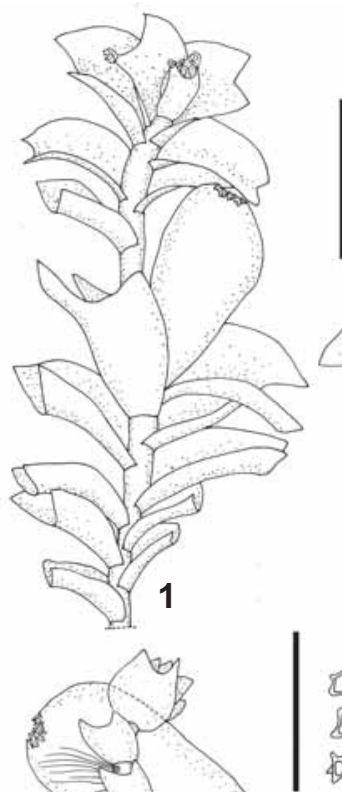
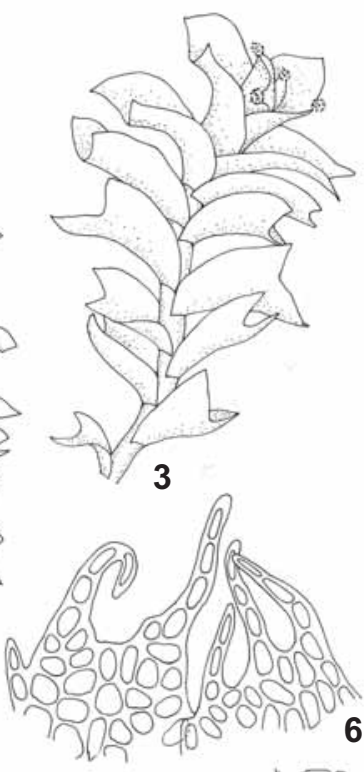

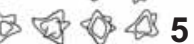

Fig. 1. Tritomaria mexicana Bakalin: 1, 2 - perianthous plants, dorsal view; 3 - gemmiparous plant, dorsal view; 4 - perianthous plant, ventral view; 5 -gemmae; 6 perianth mouth; 7 -stem cross section; 8 - cells in the midleaf (papillae are shown on the part); 9 - cells in the leaf base; 10 - female bracts; 11 - leaves. Scales: a - $1 \mathrm{~mm}$ for $1-4,10$, 11 ; b - $100 \mathrm{~mm}$ for 5-9. All from holotype (MO).

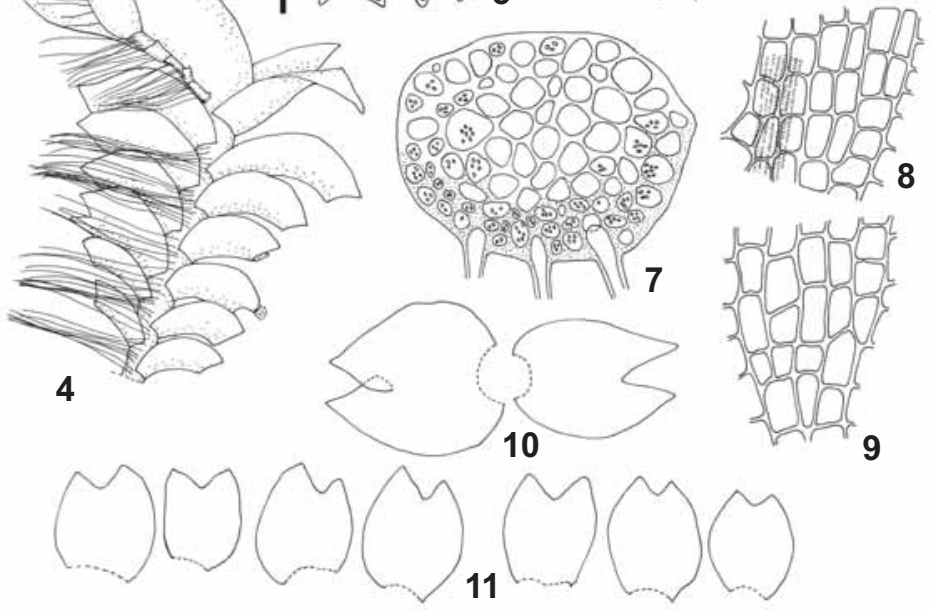

\section{LITERATURE CITED}

ARNELL, S. W. 1958. New Hepaticae from Cameroon Mountain.- Svensk Bot. Tidskr. 52(1): 63-67.

[BAKALIN, V. А.] БАКАЛИН В. А. 2005. Монографическая обработка рода Lophozia (Dumort.) Dumort. s. str. - [The monographic study of Lophozia (Dumort.) Dumort. s. str.] M., Наука [Moscow, Nauka], 239.

BEDNAREK-OCHYRA, H., J. VÁNA, R. OCHYRA \& R.I. LEWIS SMITH. 2000. The Liverwort Flora of Antarctica. - Cracow, Inst. Bot. Polish Acad.Sci., 236 pp.

ENGEL, J. J. \& D. GLENNY. 2008. A Flora of the Liverworts and Hornworts of New Zealand. Vol. 1. - Missouri, Missouri Bot. Gard. Press, 897.

GRADSTEIN, S. R. \& D. PINHIERO DA COSTA 2003. The Hepaticae and Anthocerotae of Brazil. - Mem. New York Bot. Garden 87: 1-318, f. 1-105.
GRADSTEIN, S. R. \& J. VÁNA 1987. On the occurrence of Laurasian liverworts in the tropics. -Mem. New York Bot. Garden 45: 388-425.

SCHUSTER, R. M. 1969. The Hepaticae and Anthocerotae of North America. Vol. 2. - New York and London, Columbia University Press, 1062.

SCHUSTER, R. M. 1995. Notes on Nearctic Hepaticae, XVII. Lophozia decolorans, new to North America and the subgenus Isopaches. - Bryologist. 98(2): 246-250.

SCHUSTER, R. M., K. DAMSHOLT 1974. The Hepaticae of West Greenland from ca. $66^{\circ} \mathrm{N}$ to $72^{\circ} \mathrm{N}$. - Medel. om Groenland 199(1): 1-373.

SCHUSTER, R. M. \& N. A. KONSTANTINOVA 1996. Studies on the distribution of critical arctic/subarctic Hepaticae with special reference to taxa found in Russia. - Lindbergia 21: 26-48. 